\section{Peran Genre Narkotika Di SMA Negeri 1 Kualuh Selatan Dalam Pencegahan Pemberantasan Penyalahgunaan Dan Peredaran Gelap Narkotika (P4GN) Di Labuhanbatu Utara} oleh:

Indra Kumalasari $\mathbf{M}^{\mathbf{1}}$

Email: Indrakumalasarim@gmail.com

\begin{abstract}
Abstrak
Adanya temuan bagi siswa yang menggunakan Narkotika berawal dari coba-coba, hal ini sangat berpengaruh pada prilaku siswa itu sendiri. hal ini terjadi dikarenakan kurang aktifnya peran dari GenRe Narkotika dalam implementasi dari program pencegahan pemberantasan penyalahgunaan dan peredaran gelap narkotika (P4GN) di Kabupaten Labuhanbatu Utara. Tujuan dari Penelitian ini adalah untuk mengetahui peran dari GenRe narkotika yang sudah dibentuk di SMA Negeri 1 Kualuh selatan dalam upaya pencegahan peredaran gelap narkotika dikalangan siswa.
\end{abstract}

Hasil penelitian ini yaitu SMA Negeri 1 Kualuh Selatan telah membentuk GenRe Narkotika sebagai upaya dalam pencegahan peredaran gelap narkotika sebagaimana amanah dari undang-undang no 35 tahun 2009 tentang narkotika. Akan tetapi GenRe narkotika yang sudah dibentuk ini belum efektif sebagaimana perannya dikarenakan hanya aktif pada ajang kopetisi peran GenRe narkotika pada tingkat provinsi. Pengetahuan tentang bahaya narkotika yang mempunyai sanksi hukum bagi pengedar dan pengguna masih belum baik dalam penguasaan dasar materi. Diharapkan pada pihak sekolah untuk lebih memberikan pengetahuan materi lebih baik lagi dan pihak sekolah lebih aktif lagi melibatkan akademisi dalam hal ini pihak yang mempunyai peran utama diantaranya penegak hukum, pemerintah daerah ataupun BNNK Labuhanbatu utara Dan bagi pemerintah daerah lebih aktif dan mensuport GenRe Narkotika yang sudah ada

\footnotetext{
${ }^{1}$ Dosen Fakultas Hukum, Universitas Labuhanbatu
}

seperti halnya Ddi SMA Negeri 1 Kualuh Selatan Labuhanbatu Utara.

Kata kunci: Peran GenRe Narkotika dalam Pencegahan dan Pemberantasan.

\section{Abstract}

The findings about the students who use narcotics are originated from trial and error. It is very influential on the behavior of the students themselves. This happens due to the inactivity of the role of narcotics genre in the implementation of the prevention program to eradicate abuse and illicit drug trafficking in North Labuhanbatu Regency. The purpose of this study was to determine the role of the narcotics genre that had been formed at SMA Negeri 1 South Kualuh in order to prevent illicit drug trafficking among students.

The results of this study showed that the students of SMAN 1 South Kualuh has established the Narcotics Genre as an effort in the prevention of illicit trafficking of narcotics as well as the mandate of law No. 35 of 2009 on narcotics. However, the narcotics genre that has been formed has not been as effective as its role because it is only active at the provincial level competition for the role of narcotics genre. Knowledge about the danger of narcotics that have legal sanctions for the dealers and users is still not good in mastering the basic material. It is expected that the school will provide better material knowledge about the danger of narcotics and the school is more active in involving academics in this case those who have the main role include law enforcement, local government or North Labuhanbatu BNNK. Moreover, it is suggested for the local governments to be more active and to support the Narcotics Genre which already exists as well as at SMA Negeri 1 South Kualuh in North Labuhanbatu.

Keywords: Narcotics GenRe Role in Prevention and Eradication 
Media Komunikasi dan Informasi Hukum dan Masyarakat

\section{PENDAHULUAN}

\section{A. Latar Belakang Masalah}

Indonesia adalah negara yang mempunyai wilayah yang sangat luas dengan jumlah penduduk yang cukup padat terkhusus diwilayah perkotaan. Terlepas dari semua itu semakin banyak jumlah penduduk samakin rentan akan tindak pidana kejahatan dikarenakan salah satu faktor utama adalah minimnya lapangan pekerjaan dan masih rendahnya sumber daya manusianya yang ada. Faktor Ekonomi merupakan salah satu penyebab seseorang melakukan tindak pidana. Kejahatan yaitu perilaku yang merugikan atau perilaku yang bertentangan dengan ikatanikatan sosial (anti sosial) atau perilaku yang tidak sesuai dengan pedoman masyarakat ${ }^{2}$. Kejahatan merupakan prilaku sosial yang melanggar ketentuan peraturan perundangundangan yang sifatnya megatur tata tertib yang bertujuan untuk kepentingan umum. Semakin banyaknya prilaku penyimpangan yang dilakukan oleh masnyarakat tidak terlepas dari perlunya tuntutan dalam mengimplementasikan sistem hukum.

Peneliti berpendapat bahwa sistem hukum adalah suatu bagian yang terdiri dari peraturan perundang- undangan, penegak hukum dan masnyarakat. Ketiga bagian dari sistem tersebut harus sejalan dalam memberantas kejahatan yang ada di negeri ini. Peneliti melihat keadaan sosial masnyarakat di indonesia banyaknya pelanggaran hukum dikarena sistem hukum tidak berjalan dengan baik, peraturan yang sudah ada akan tetapi tidak dijalankan dengan baik oleh penegak hukum itu sendiri serta masih acuhnya sikap

\footnotetext{
2 Bambang Poernomo, 1990, Orientasi Hukum Acara Pidana Indonesia, Yogyakarta: Amarta Buku, Halaman 4
}

masnyarakat dalam keadaan tersebut sehingga pelaksanaan penegakan hukum di negeri ini tidak dapat menjalankan fungsinya sesuai dengan kewajiban yang sudah ditentukan dalam undang-undang.

Indonesia tidak pernah bebas dari peredaran gelap narkotika, kejahatan narkotika merupakan kejahatan sangat luar biasa hal ini disebabkan dikarenakan pelakunya baik pengedar dan penggunanya sama-sama melanggar peraturan perundang-undangan sebagaimana diatur dalam Undang-undang nomor 35 tahun 2009 tentang Narkotika.Ironisnya sekarang pengguna narkotika sudah sampai pada generasi muda yaitu pada pelajar hal ini terjadi pada Tahun 2017 telah ditemukan siswa di Kabupaten Labuhan batu Utara mengkonsumsi narkotika golongan I yaitu ganja. Siswa mengkonsumsi narkotika karena penasaran terhadap rasa ganja sehingga mengikuti ajakan teman untuk mengkonsumsinya. ${ }^{3}$ Perilaku sebagian remaja yang secara nyata telah jauh mengabaikan nilainilai kaidah dan norma serta hukum yang berlaku di tengah kehidupan masyarakat menjadi salah satu penyebab maraknya penggunaan narkoba di kalangan generasi muda. Dalam kehidupan sehari-hari di tengahtengah masyarakat masih banyak dijumpai remaja yang masih melakukan penyalahgunaan narkotika. Berkaitan dengan hal tersebut peneliti memfokusnya kajian terhadap dibentukan gendre narkotika di SMA Negeri 1 Kualuh Selatan kabupaten Labuhanbatu Utara, sebagai upaya generasi muda untuk turut serta

${ }^{3}$ Indra dkk, Implementasi Kebijakan Harm Reduction untuk Meningkatkan Moral Knowing tentang Narkotika pada Siswa SMA di Kabupaten Labuhanbatu Utara, Sumatera Utara Jurnal Pengabdian Pada Masyarakat. Vol. 5, No. 1, 2020, Halaman 19 
membantu pemerintah dalam program indonesia bebas dari narkotika.

\section{B. Rumusan Masalah}

1. Apa Landasan hukum dibentukanya genre narkotika dalam mencegah peredaran gelap narkotika di labuhanbatu utara?

2. Bagaimana cara siswa SMU Negeri 1 kualauh selatan dalam melakukan pencegahan pemberantasan penyalahgunaan dan peredaran gelap narkotika ( P4GN ) di Labuhanbatu Utara?

\section{METODE PENELITIAN}

Penelitian ini bersifat deskriptif karena penelitian ini semata-mata menggambarkan suatu objek untuk menggambil kesimpulankesimpulan yang berlaku secara umum ${ }^{4}$. Dalam penelitian ini penulis akan mendekripsikan penelitian ini berkaitan dengan Peran gendre narkotika di SMU Negeri 1 Kualuh Selatan dalam Pencegahan Pemberantasan Penyalahgunaan Dan Peredaran Gelap Narkotika (P4GN) di Kabupaten Labuhanbatu Utara. Penelitian ini dengan menggunakan Metode penelitian hukum Normatif - Empiris. Metode ini pada dasarnya ialah penggabungan antara pendekatan hukum normatif dengan adanya penambahan dari berbagai unsur-unsur empiris. Metode penelitian normatif-empiris ini juga menganalisa tentang implementasi ketentuan hukum normatif Undang-undang Nomor 35 Tahun 2009 Tentang Narkotika, dalam aksinya disetiap peristiwa hukum tertentu yang terjadi dalam suatu masyarakat terkait peredaran gelap narkotika di kabupaten labuhanbatu utara. Dalam penelitian hukum

\footnotetext{
${ }^{4}$ Sutrisno Hadi, Metodologi Research I, (Yogyakarta : Yayasan Penerbitan Fak. Psikologi UGM, 1986), Halaman 3
}

normatif-empiris ini peneliti memfokuskan dengan memakai Pendekatan live case study yaitu pendekatan pada suatu peristiwa hukum yang terjadi di kalangan kaum pelajar terkait penyalahgunaan narkotika.

\section{PEMBAHASAN}

Mendengar kata narkotika di ucapkan, seringkali memberi bayangan tentang dampak yang tidak inginkan, hal ini dikarenakan narkotika identik sekali dengan perbuatan jahat, terlarang dan melanggar peraturan. Narkotika merupakan bagian dari narkoba, yaitu segolongan obat, bahan atau zat yang apabila masuk ke dalam tubuh akan berpengaruh terutama pada jalannya fungsi otak (susunan syaraf pusat) dan sering menimbulkan ketergantungan, terjadi perubahan dalam kesadaran, pikiran, perasaan, dan perilaku pemakainya. $^{5}$

Ada lima faktor utama penyebab seorang rawan terhadap narkotika atau kecanduan terhadap hal-hal lain. Penyebab itu adalah keyakinan adiktif, kepribadian adiktif, ketidakmampuan menghadapi masalah, tidak terpenuhinya kebutuhan emosi, sosial, dan spiritual, serta kurangnya dukungan sosial. ${ }^{6}$ Narkotika dapat menimbulkan adiksi (ketagihan) yang nantinya dapat berakibat depresi (ketergantungan) yang memiliki sifat-sifat sebagai berikut:

1. Keinginan yang tak tertahankan (an overpowering desire) terhadap narkotika;

2. Kecenderungan untuk menambah takaran (dosis);

\footnotetext{
${ }^{5}$ Ahmadi Sofyan, Narkoba Mengincar Anak Anda, Prestasi Pustaka, Jakarta, 2007, HIm. 12.

${ }^{6}$ Lydia Harlina Martono dan Satya Joewana, Pencegahan dan Penanggulangan Penyalahgunaan Narkoba berbasis Sekolah, PT. Balai Pustaka, Jakarta, 2006, HIm. 20.
} 
Media Komunikasi dan Informasi Hukum dan Masyarakat

3. Ketergantungan psikologis, yaitu apabila pemakaian narkotika dihentikan maka akan menimbulkan gejala kejiwaan;

4. Ketergantungan fisik, yaitu apabila pemakaian narkotika dihentikan akan menimbulkan gejala fisik (gejala putus obat). ${ }^{7}$

Apalagi peredaran narkotika pada zaman sekarang ini tidak hanya terdapat pada kota-kota besar akan tetapi sudah masuk ke semua lapisaan masyarakat baik dari kalangan atas, menengah, bahkan kalangan bawah sekalipun.

Pelajar SMA Negeri 1 Kualuh Selatan adalah sekolah yang berada di kabupaten labuhanbatu utara tepatnya dikecamatan kulauh selatan. Sekolah ini berkeinginan kuat untuk turut serta membantu pemerintah dalam hal penegakan hukum tentang pencegahan pemberantasan penyalahgunaan dan peredaran gelap narkotika (P4GN). Dasar dibentukanya Gendre Narkotika dikalangan pelajar yaitu berdasarkan Undang-undang nomor 35 tahun 2009 tentang Narkotika. Terkait peran serta masnyarakat dalam mencegah peredaran narkotika tertuang dalam BAB XIII Pasal 104 Masyarakat mempunyai kesempatan yang seluas-luasnya untuk berperan serta membantu pencegahan dan pemberantasan penyalahgunaan dan peredaran gelap Narkotika dan Prekursor Narkotika.Selanjutnya Intruksi Presiden nomor 6 tahun 2008 tentang Rencana Aksi Nasional Pencegahan dan pemberantasan penyalahgunaan dan peredaran gelap narkotika dan prekursur narkotika. Selanjutnya Peraturan Bupati Labuhanbatu Utara Nomor 14 Tahun 2017 Tentang Satuan Tugas Pemberantasan, Pencegahan Penyalahgunaan Dan Peredaran

\footnotetext{
${ }^{7}$ Mardani, Penyalahgunaan Narkoba dalam Perspektif Hukum Islam dan Hukum Pidana Nasional, Rajawali Pers, Jakarta, 2008, HIm. 2.
}

Gelap Narkotika Di Kabupaten Labuhanbatu Utara.

Narkotika adalah Zat/obat yg berasal dari tanaman atau bukan tanaman (sintetis maupun semi sintetis) yang menyebabkan penurunan/perobahan kesadaran, hilangnya rasa dan juga rasa sakit serta dapat menimbulkan ketergantungan, dan Psikotropika Yaitu Zat/obat baik alamiah maupun sintetis (bukan narkotika), yang mempengaruhi syaraf pusat menyebabkan perobahan pada aktivitas mental dan perilaku. Sedangkan Zat adiktif yaitu Yang berasal dari tanaman atau bukan tanaman (sentetis maupun semi sintetis) yang menyebabkan ketergantungan dan menurunkan susunan syaraf pusat, namun dalam penyalahgunaan narkotika bisa mengakibatkan ketergantungan dan melanggar peraturan perundang-undangan karena sifatnya ilegal.

Melalui progarm GenRe Narkotika, SMA Negeri ini Kualuh Selatan ini ingin membangun kesadaran kaum muda betapa berbahaya narkoba sehingga tak mudah terbujuk rayuan bandar narkoba yang mengintai di luar dari lingkungan masnyarakat. Penggunaan narkoba banyak dilakukan oleh remaja atau kelompok usia muda. Hal ini tidak terlepas dari sifat remaja yang mempunyai rasa ingin tahu yang lebih besar. ${ }^{8}$

GenRe Narkotika ini dibentuk di sekolah dengan tujuannya yaitu untuk membantu pemerintah dalam program pencegahan pemberantasan penyalahgunaan dan peredaran gelap narkotika (P4GN) terkhusus di kabupaten Labuhanbatu Utara. Program GenRe ini dilaksanakan dengan cara mensosialisasikan dilingkungan sekolah bahwa dengan mengunakan Narkotika bisa menghancurkan masa depan bangsa, namun

\footnotetext{
${ }^{8}$ Sri purwatiningsih, penyalahgunaan narkoba di indonesia.jurnal kependudukan dan kebijakan Halaman 43
} 
Media Komunikasi dan Informasi Hukum dan Masyarakat

peneliti melihat masih kurang efektifnya program ini dikarenakan kurang dukungan dari pemerintah kabupaten labuhanbatu utara, dikarenakan GenRe ini tidak disosialisasikan kepada sekolah-sekolah yang ada di Kabupaten labuhanbatu utara. lebih lanjut menurut peneliti peredaran narkotika sudah pada generasi muda, Karena pemuda sebagai generasi yang diharapkan menjadi penerus bangsa, semakin hari semakin rapuh digerogoti zat-zat adiktif penghancur syaraf sehingga pemuda tersebut tidak dapat berpikir jernih, Akibatnya, generasi harapan bangsa yang tangguh dan cerdas hanya akan tinggal kenangan.Sasaran dari penyebaran narkoba ini adalah kaum muda atau remaja. Usia sasaran Narkotika ini adalah usia pelajar, yaitu berkisar umur 11 sampai 18 tahun.

$$
\text { Maraknya Peredaran Narkotika }
$$

dilabuhanbatu utara sangat mempengaruhi moral masnyarakat terkhusus generasi muda dikarenakan dapat menimbulkan ketergantungan (adiksi) fisik dan psikologis Penyalahgunaan narkotika dan obat-obatan terlarang di kalangan generasi muda dewasa ini kian meningkat Maraknya penyimpangan perilaku generasi muda tersebut, dapat membahayakan keberlangsungan hidup bangsa ini di kemudian hari. Katakan Tidak Pada Narkoba adalah sebuah niat, ucapan dan tindakan yang wajib dilakukan untuk memerangi penyalahgunaan Narkoba, bukan hanya hanya sebatas tertulis dan terucap saja tanpa aplikasi, akan tapi perlu adanya sebuah tindakan nyata yang harus dilakukan oleh generasi muda ini.

Pemerintah Kabupaten Labuhanbatu Utara melalui Badan Kesatuan Bangsa dan Politik (Kesbangpol) menggelar sosialisasi Pencegahan Pemberantasan Penyalahgunaan dan Peredaran Gelap Narkotika (P4GN).Acara sosialisasi $\mathrm{P} 4 \mathrm{GN}$ itu digelar pada hari Selasa
(8/10) di Aula Ahmad Dewi Syukur, H. Endar Sakti, Hasibuan mewakili Bupati Labura $\mathrm{H}$. Kharuddin Syah, SE membuka sosialisasi P4GN sekaligus membacakan pidato tertulis Bupati. ${ }^{9}$ Berdasarkan hal tersebut peneliti berpendapat kegiatan yang dilakukan oleh pemerintah daerah hanya sebatas serimonial saja seharusnya pemerintah lebih aktif lagi mensosialisakan ke dunia pendidikan terkhusus kesekolah-sekolah dan bekerja sama dengan pihak yang punya kopetensi dibidangnya seperti dari bidang kesehatan serta dibidang penegak hukum. Penyelesaian permasalahan narkotika harus diselesaikan dengan sistem yang baik yaitu mulai dari unsur pemerintahan, penegakan hukum sampai pada masnyarakat yang sangat berperan penting dalam pemberantasan dan pencegahan peredaran narkotika sebagaimana amanah dari undang- undang nomor 35 tahun 2009 tentang narkotika yang tertuang dalam pasal 105 yang menyatakan bahwa Masyarakat mempunyai hak dan tanggung jawab dalam upaya pencegahan dan pemberantasan penyalahgunaan dan peredaran gelap narkotika dan Prekursor Narkotika.

Program GenRe adalah program yang mengedepankan pembentukan karakter bangsa dikalangan generasi muda. Program GenRe merupakan wadah untuk mengembangkan karakter bangsa karena mengajarkan remaja untuk menjauhi NAPZA (Narkotika, Psikotropika, dan Zat Adiktif) guna menjadi remaja tangguh dan dapat berkontribusi dalam pembangunan serta berguna bagi nusa dan bangsa. Keberadaan duta Genre sekaligus menekan maraknya permasalahan remaja, dan yang paling menonjol adalah permasalahan seputar penyalahgunaan narkoba dan rendahnya

\footnotetext{
${ }^{9}$ https://labura.go.id/pemkab-labura-gelarsosialisasi-p4gn/diakses pada tanggal 5 Mei 2020
} 
Media Komunikasi dan Informasi Hukum dan Masyarakat

pengetahuan tentang kesehatan bagi pengguna dan kurang pahamnya akan sanksi hukum bagi pelaku pengedar dan pemakai narkotika yang relatif masih rendah serta masih banyaknya menimpa remaja, sehingga peran duta Genre perlu terus digiatkan dalam hal melakukan sosialisasi kesekolah-sekolah dan melibatkan pihak yang punya peran penting dalam program P4GN terkhusus untuk wilayah kabupaten Labuhanbatu Utara.

\section{Pentingnya Mensosialisasikan Peran GenRe Narkotika dalam pola hidup siswa}

Tindakan preventif adalah tindakan yang dilakukan untuk mencegah atau menjaga kemungkinan yang akan terjadi dalam kejahatan. ${ }^{10}$ Siswa perlu mengampanyekan kepada remaja agar mempunyai target pendidikan dan keterampilan hidup agar kelak mempunyai keberanian untuk menghadapi dan mengatasi masalah dan kesulitan dalam hidup sehari-hari. Perlunya keterampilan hidup bagi remaja yaitu:

1. Membantu remaja mencapai tugas dan perkembangan pribadi, antara lain pertumbuhan fisik, perkembangan mental, perkembangan emocional, dan perkembangan spiritual.

2. Membantu remaja mncapai tugas pertumbuhan dan perkembangan sosial, antara lain melanjutkan sekolah, mencari pekerjaan, memuli kehidupan berkeluarga, menjadi anggota masyarakat dan mempraktekkan hidup sehat.

Program GenRe yang dikampanyekan kesekolah-sekolah yang ada dilabuhanbatu

\footnotetext{
${ }^{10}$ Indra dkk, Implementasi kebijakan harm reduction,Deepublish publiser. Yogyakarta 2019, Halaman54
}

utara bertujuan untuk memfasilitasi remaja agar belajar memahami dan mempraktikkan perilaku hidup sehat dan berakhlak untuk mencapai ketahanan, serta agar remaja memahami dan mempraktekkan pola hidup sehat dan berakhlak, pola hidup yang berketahanan sehingga dapat mempersiapkan diri menjadi generasi yang cerdas dan kuat.

GenRe punya peranan penting dalam mengedukasi rekan sebaya, untuk menghindari sejumlah permasalahan sosial seperti bahaya Narkoba di kalangan generasi muda. peneliti berharap GenRe Narkotika ini tak hanya mengedukasi siswa, namun juga mampu menjadi agen perubahan di tengah-tengah masyarakat, terutama tempat tinggal masingmasing, dalam mensosialisasikan bahaya Narkoba. Dalam mengantisipasi serangan narkotika dilabuhanbatu utara, berbagai upaya harus di lakukan baik itu lewat sosialisasi di lingkungan sekolah-sekolah maupun dilingkungan masyarakat. Perlunya dorongan dari pemerintah daerah untuk membantu keterbatasan anggaran yang ada disekolah dalam mensosialisasikan GenRe Narkotika di lingkungan sekolah diseluruh wilayah kabupaten labuhanbatu utara. peneliti berharap, masyarakat terpanggil untuk ikut berperan dalam mengantisipasi bahaya Narkoba minimal di lingkungan Keluarga dan terus giat untuk menyadarkan masyarakat tentang bahaya Narkotika.

Promosi GenRe Narkotika ini digencarkan untuk mengajak para remaja berperilaku sehat dan berakhlak, mengatakan tidak pada narkotika, dan tidak menjadi korban, sehingga remaja ini kedepannya dapat merencanakan kehidupan dan masa depan yang lebih baik dalam membangun kemajuan 
Media Komunikasi dan Informasi Hukum dan Masyarakat

bangsa dan negara kesatuan republik indonesia.

Faktor yang paling dominan yang menyebabkan terjadinya penyalahgunaan narkoba di kalngan remaja adalah disebabkan karena faktor pergaulan, hal ini didasarkan pada kesimpulan dari hasil wawancara langsung dari informan yang menyatakan bahwa faktor pergaulan dengan teman sebaya yang terlalu bebas dan tidak terkontrol menyebabkan remaja ikut terjerumus melakukan penyalahgunaan narkoba. Penelitian ini juga menemukan bahwa faktor pergaulan menjadi pendorong siswa dalam penyalahgunaan NAPZA $^{11}$. Hasilpenelitian menunjukkanbahwa faktor yang menyebabkan para remaja menyalahgunakan narkoba di antara faktor keluarga yang kurang memperhatikan anaknya,dan juga faktor lingkungan juga dapat berpengaruh besar. Dengan pendidikan dan pendidikan agama adalah sebagai tembok paling luar mencegah penyalagunaan narkoba ${ }^{12}$. Terdapat perbedaan yang signifikan antara risiko penyalahgunaan NAPZA pada subjek laki-laki dan perempuan dimana remaja laki-laki lebih berisiko pada penyalahgunaan NAPZA dibandingkan remaja perempuan ${ }^{13}$. Permasalahan remaja bukan hanya memerlukan aturan dan sanksi yang tegas kepada siswa, ataupun pengawasan yang ekstra

\footnotetext{
${ }^{11}$ Simangunsong. J. 2015. Penyalahgunaan Narkotika di Kalangan Remaja.

${ }^{12}$ Wibawan. T. 2013. Bahaya Narkoba di Kalangan Remaja.

${ }^{13}$ Riyadi. 2015. Risiko Penyalahgunaan Napza Pada Remaja Ditinjau Dari Jenis Kelamin, Status Tinggal Dan Status Orang tua
}

ketat dari guru selama siswa berada dalam lingkungan sekolah. Tetapi diperlukan pula proses edukatif yang mendidik agar siswa mendapatkan informasi yang jelas tentang bahaya penyalahgunaan NAPZA melalui penyuluhan maupun konseling oleh pengelola PIK Remaja Teenage Health $\mathrm{S}^{14}$.

\section{PENUTUP}

\section{A. Kesimpulan}

Kehidupan remaja yang rentan terhadap NAPZA, untuk itu perlu disikapi dengan memberikan edukasi yang lebih tentang kesehatan dan adanya sanksi hukum bagi pengguna dan pelaku pengedar narkotika berdasarkan Undang-undang nomor 35 tahun 2009 tentang narkotika, serta mempersiapkan masa depan merka yang baik.

Peran GenRe Narkotika Dalam hal ini konselor sebaya sangat penting, karena dianggap lebih dapat diterima oleh jiwa remaja. Dalam hal siswa berpengaruh untuk mengampanyekan program GenRe Narkotika dengan melakukan beberapa langkah yang ditempuh untuk mewujudkan tujuan dikembangkannya program Genre yang telah dibentuk oleh SMA Negeri 1 Kualuh Selatan Kabupaten Labuhanbatun Utara dan kedepan terkhusus pemerintah Kabupaten Labuhanbatu Utara menyiapkan para remaja dalam hal jenjang pendidikan yang terencana sebagai

\footnotetext{
${ }^{14}$ Ashar.Dkk. 2017.Peran Pusat Informasi Konseling Remaja dalam Penanggulangan Permasalahan NAPZA di SMU Negeri 5 Makassar. JurnalAnalisis. Vol. 6: (1).
} 
Media Komunikasi dan Informasi Hukum dan Masyarakat

upaya peran pendidikan untuk membentuk karakter siswa tersebut sebagai capaian akhir dalam Berkarir dalam pekerjaan yang terencana.

\section{B. Saran}

Bagi Pemerintah Terkhusus Pemerinta Kabupaten Labuhanbatu Utara harus benarbenar konsiten dalam program P4GN dengan mengimplementasikan dengan sistem yaitu mulai dari melibatkan penegak hukum, intansi yang mempunyai peran penting seperti BNNK Labuhanbatu Utara dan melibatkan masnyarakat serta GenRe Narkotika yang sudah dibentuk oleh SMA Negeri 1 Kualuh Selatan Kabupaten Labuhanbatun Utara.

\section{Daftar Bacaan}

Ahmadi Sofyan, Narkoba Mengincar Anak Anda, Prestasi Pustaka, Jakarta, 2007

Indra dkk, 2019. Implementasi kebijakan harm reduction,Deepublish Publiser. Yogyakarta

Lydia Harlina Martono dan Satya Joewana, Pencegahan dan Penanggulangan Penyalahgunaan Narkoba berbasis Sekolah, PT. Balai Pustaka, Jakarta, 2006

Mardani, Penyalahgunaan Narkoba dalam Perspektif Hukum Islam dan Hukum Pidana Nasional, Rajawali Pers, Jakarta, 2008

Poernomo Bambang., 1990, Orientasi Hukum Acara Pidana Indonesia, Amarta Buku, Yogyakarta.

Purwatiningsih Sri, 2001. Penyalahgunaan Narkoba dilindonesia. Populasi jurnal kependudukan dan kebijakan. Universitas Gadjah Mada. Vol. 12 No. 1

Sutrisno Hadi, 1986, Metodologi Research I, Yogyakarta: Yayasan Penerbitan Fak. Psikologi UGM..

https://labura.go.id/pemkab-labura-gelarsosialisasi-p4gn/diakses pada tanggal 5 Mei 2020 